\title{
LEGAL ANALYSIS OF THE CAUSES AND EFFECTS OF THE FINANCIAL SPIRAL
}

\section{PRAWNA ANALIZA PRZYCZYN I SKUTKÓW SPIRALI FINANSOWEJ}

\begin{abstract}
The research goal of the article is to analyze the financial spiral in legal and dogmatic terms. The subject of the research are the reasons and more precisely the effects of the financial spiral. In this context, the legal status of the financial spiral is diagnosed in combination with the subjective factors of the potential borrower.

The legal-dogmatic method, analysis and synthesis were used.

The discussed problem of the financial spiral is a growing threat to social security and at the same time to the financial security of the country. The problem of the nonbanking sector activity and the standards of providing financial services remains unresolved. Consumer bankruptcy is one of the final solutions - the reduction or cancellation of obligations of a natural person not conducting business activity in the event of a state of non-performing insolvency was introduced on March 31, 2009 into Polish bankruptcy and reorganization law.

Applications de lege ferenda and de lege years applications. Summing up, it can be concluded that the discussed issues regarding the application of the Consumer Credit Act are significantly circumvented. The presented examples of gaps and practical interpretations on the basis of current regulations are unacceptable in a modern legal state.
\end{abstract}

\section{STRESZCZENiE}

Spirala zadłużenia wciąga coraz większą liczbę osób. Dotyczy przede wszystkim osób fizycznych, a tym samym gospodarstw domowych. Problem spirali finansowej występuje również, choć w mniejszym stopniu, wśród przedsiębiorców. Chodzi o osoby fizyczne prowadzące działalność gospodarczą, które tracąc bieżącą płynność, 
posiłkują się pożyczkami w dostępnych firmach pożyczkowych. Dostępność pożyczek w połączeniu z podejmowaniem decyzji finansowych pod wpływem ignorancji tematu wespół $\mathrm{z}$ emocjami i impulsami to niebezpieczne połączenie. Mechanizm produktów finansowych oferowanych przez firmy pożyczkowe wywołuje zadłużenie o zaskakującej pożyczkobiorców wielkości, które trudno kontrolować już na etapie zaciągnięcia pożyczki.

Według wielu źródeł (Diagnoza Społeczna 2015. Warunki i jakość życia Polaków, dane statystyczne GUS i inne) zadłużenie osób fizycznych i gospodarstw domowych osiąga coraz większe wartości. Doświadczenia kancelarii prawnych oraz kancelarii komorniczych wskazują, że rośnie także liczba osób popadających w stan całkowitej niewypłacalności. Część z tych przypadków na skutek zawiadomień złożonych przez wierzycieli pożyczkowych wyczerpuje znamiona czynu zabronionego określonego w art. 286 Kodeksu karnego i staje się podstawą do skazania pożyczkobiorcy za zaciąganie kolejnych pożyczek mimo wystąpienia obiektywnej niewypłacalności.

KEYWORDs: financial spiral, indebtedness, a natural person, bankruptcy, spiral of debt

SŁOWA KLUCzowe: spirala finansowa, zadłużenie, osoba fizyczna

\section{WPROWADZENIE}

Problematykę współczesnej spirali finansowej w pewnym sensie ukonstytuowało wejście w życie Ustawy z dnia 12 maja 2011 r. o kredycie konsumenckim. Polski ustawodawca chcąc podążać za trendami światowych rynków finansowych, postanowił dopuścić do legalnej działalności firmy, które pożyczają własne pieniądze. Jednocześnie zakładał, iż wyeliminuje to, a co najmniej ograniczy, szarą strefę pożyczek udzielanych przez grupy przestępcze. Ustawa o kredycie konsumenckim dokonała liberalizacji katalogu czynności bankowych zastrzeżonych dla banków. W istocie koncepcja leżąca u podstaw tej inicjatywy ustawodawczej zakładała, iż dopuszczenie do legalnego obrotu firm, które pożyczają własne pieniądze, nie wpłynie na pogorszenie bezpieczeństwa finansowego kraju ani bezpieczeństwa społecznego. Z założenia firmy, które pożyczają własne pieniądze, samodzielnie ponoszą ryzyko kredytowe, a tym samym nie jest konieczne obejmowanie ich wyspecjalizowanym nadzorem bankowym. Ponadto pomysłodawcom tej ustawy zależało, aby zdynamizować rynek kredytowy, a tym samym aby banki w obliczu konkurencji zmniejszyły koszty kredytu bankowego. 
Przedmiotem niniejszego artykułu są przyczyny oraz - przede wszystkim - skutki spirali finansowej. Przeprowadzona jest w nim diagnoza stanu prawnego spirali finansowej w połączeniu z czynnikami subiektywnymi potencjalnego pożyczkobiorcy.

Celem badawczym artykułu jest analiza spirali finansowej w ujęciu prawno-dogmatycznym. W tym kontekście należy postawić pytanie: kto i dlaczego sięga po produkty finansowe firm pożyczkowych? Ponadto warto próbować odpowiedzieć na pytanie: czy legalizacja działalności firm pożyczkowych $\mathrm{i}$ ich funkcjonowanie równolegle $\mathrm{z}$ działalnością sektora bankowego jest właściwym krokiem ewolucyjnym z punktu widzenia bezpieczeństwa społecznego? Badania diagnostyczne zostały przeprowadzone w oparciu o raporty Narodowego Banku Polskiego i biorąc pod uwagę raporty firm badających zjawisko zadłużania się osób fizycznych (Bywalec, 2012, s. 206-213). Zasadniczo wykorzystano metodę prawno-dogmatyczną oraz analizę i syntezę.

\section{CZYM JEST SPIRALA ZADEUŻENIA?}

Można przyjąć, że spirala finansowa (spirala długów) to duża różnica pomiędzy wysokością naszych wpływów a wysokością zobowiązań finansowych, które musimy pokryć (zwłaszcza pożyczek) (Grzywińska-Rąpca, 2018, s. 165-184).

Będąc w spirali zadłużenia, nie jesteśmy w stanie spłacać zaciągniętych zobowiązań. Ich kwoty przewyższają bowiem nasze możliwości finansowe. W przypadku narastania zatoru płatniczego w kolejnych okresach sprawozdawczych niektóre osoby decydują się na zaciągnie kolejnych pożyczek, aby spłacać już istniejące. Podstawowym okresem sprawozdawczym dla osoby fizycznej jest jeden miesiąc. Niestety, w przypadku zaistnienia zbiegu kilku czynników dochodzi o zupełnego zatoru płatniczego i niewydolności finansowej osoby fizycznej czy gospodarstwa domowego.

\section{PrZYCZYNY SPIRALI ZADEUŻENIA}

Pierwszą i podstawową przyczyną jest skorzystanie z wolnego wyboru w zakresie usług pożyczkowych, jaki oferuje legalny rynek w Polsce każdej osobie posiadającej pełną zdolność do czynności prawnych. I należy to podkreślić już na początku wywodu. Nie gaśnie społeczne oczekiwanie, że państwo powinno chronić obywateli przed wszelkim złem i wszelką szkodą 
materialną. Trzeba zwrócić uwagę, iż analizowana tematyka leży u podstaw prawa cywilnego, czyli stosunków prywatnoprawnych. Tylko prawidłowe rozumienie właściwości i natury norm cywilnych warunkuje prawidłowy rozwój i funkcjonowanie młodego człowieka a później pracownika i obywatela.

Osoba fizyczna korzystając ze swoich praw i wolnego wyboru, może skorzystać z usług oferowanych w ramach dwóch legalnych i jednego nielegalnego obszaru pożyczkowego.

Rysunek 1.

Obrazowe przedstawienie dostępnych rynków pożyczkowych
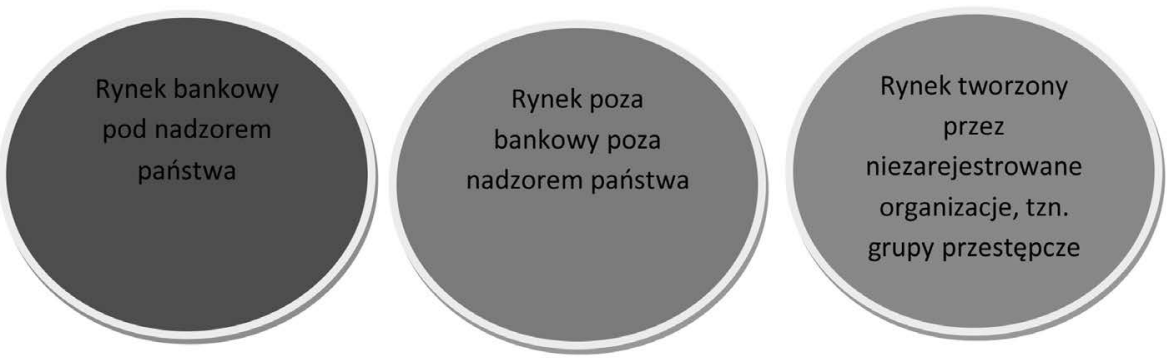

Źródło: opracowanie własne.

Podstawy prawne i zasady zaciągania kredytów na rynku bankowym wynikają przede wszystkim z Ustawy z dnia 29 sierpnia 1997 r. Prawo bankowe (Dz.U. z 2017 r. poz. 1876, 2361).

Zgodnie z polskim prawem udzielanie kredytów jest czynnością bankową sensu stricto (art. 5 ust. 1 ustawy Prawo bankowe), co oznacza, iż jest zastrzeżone jest wyłącznie dla banków. Wyjątkiem jest przypadek, gdy szczególne przepisy wprost dają taką możliwość innemu podmiotowi (np. na mocy ustawy o spółdzielczych kasach oszczędnościowo-kredytowych). Należy podkreślić, iż banki oraz spółdzielcze kasy oszczędnościowo-kredytowe (SKOK-i) podlegają nadzorowi bankowemu realizowanemu przez Komisję Nadzoru Finansowego, stosują przepisy prawa bankowego oraz procedury wewnętrze wydawane w zgodzie z prawem bankowym i innymi ustawami. Szczególną cechą banków i SKOK-ów jest możliwość udzielania kredytów ze środków uzyskanych z wpłat depozytariuszy. Mówiąc dosłownie, udzielają one kredytów ze środków, które uzyskały tytułem zwrotnym. Podmioty, które 
bez zezwolenia KNF-u prowadziłyby działalność polegającą na gromadzeniu środków pieniężnych innych osób fizycznych (depozyty-lokaty), osób prawnych lub jednostek organizacyjnych niemających osobowości prawnej w celu udzielania kredytów, pożyczek pieniężnych lub obciążania ryzykiem tych środków w inny sposób, podlegają grzywnie do 10 mln złotych i karze pozbawienia wolności do lat 5.

Ważnym elementem wpływającym na korzystanie z usług rynku bankowego są istniejące na nim ograniczenia i scentralizowane systemy, co nie wstępuje na rynku pozabankowym. Mianowicie banki zrzeszają się w ramach Związku Banków Polskich, opłacając określone składki, tworzą wiele platform współpracy i wymiany informacji. Przykładowo Biuro Informacji Kredytowej zostało utworzone w 1997 r. przez banki i Związek Banków Polskich na podstawie art. 105 ust. 4 Ustawy z dnia 29 sierpnia 1997 r. Prawo Bankowe. Jest to jeden z kilku systemów funkcjonujących w służbie rynkowi bankowemu. Banki zgodnie z określoną procedurą przekazują informację o kliencie i udzielonym produkcie kredytowym. Kolejny bank może tą informację prześledzić w przypadku udzielania kolejnego kredytu. Tworzy to kilka rodzajów zabezpieczeń, ale też i obostrzeń formalnych. Zgodnie z art. 70 Prawa bankowego Bank uzależnia przyznanie kredytu od zdolności kredytowej kredytobiorcy. Przez zdolność kredytową rozumie się zdolność do spłaty zaciągniętego kredytu wraz z odsetkami w terminach określonych w umowie. Kredytobiorca jest obowiązany przedłożyć na żądanie banku dokumenty i informacje niezbędne do dokonania oceny tej zdolności. Jednocześnie bank jest zobowiązany w BIK-u i innych systemach zweryfikować potencjalnego kredytobiorcę. W przypadku negatywnych informacji o kliencie, który ma zbyt duże zadłużenie lub zakłócenia w spłacie innych kredytów, bank zgodnie z wewnętrznymi procedurami jest zobowiązany odmówić udzielenia kredytu.

Decyzja odmowna banku jest przyjmowana przez klienta $z$ niezadowoleniem. A w istocie negatywna decyzja banku jest informacją, iż zarządzanie finansami osoby fizycznej czy gospodarstwa domowego jest nieprawidłowe. Ponadto gdyby bank udzielił takiej osobie kredytu, mógłby stracić środki finansowe w ramach kredytu, które nie należą do banku, lecz do deponenta. Bank jako instytucja zaufania publicznego jest zobowiązany do najwyższej staranności w zarządzaniu powierzonymi mu środkami finansowymi. To ma 
budować i utrwalać zaufanie do sektora bankowego, a nie szerzyć panikę na rynku. Niestety klient, który otrzymał negatywną decyzję, zamiast odstąpić od dalszego zadłużania się, realizuje zamiar zaciągnięcia kredytu/pożyczki za wszelką cenę, nie zważając na ryzyko wpadnięcia w spiralę zadłużenia.

Konieczne jest przybliżenie i scharakteryzowanie stosunku prawnego łączącego bank z kredytobiorcą (w przypadku zawarcia umowy kredytowej po pozytywnej decyzji banku). Nie zawsze wydaje się być oczywiste, iż dominujący w stosunku kredytowym jest podmiot udzielający kredytu. Wierzyciel zasadniczo jest głównym kreatorem warunków kredytu. Ponadto jest uprawniony do kontroli jego wykorzystania. Wierzyciel powinien uzależniać przyznanie kredytu od zdolności kredytowej (albo posiadania odpowiedniego zabezpieczenia kredytu i posiadania wiarygodnego programu naprawczego, którego realizacja zapewni uzyskanie zdolności kredytowej w określonym czasie), przy czym nie jest zobligowany do udzielenia kredytu, nawet jeżeli wnioskodawca ubiegający się o pożyczkę ją posiada.

Bank ma obowiązek uzależnić przyznanie kredytu od zdolności kredytowej kredytobiorcy. Wybrane czynniki uwzględniane w procedurze badania zdolności kredytowej (analizy kredytowej) to:

1. W przypadku osoby fizycznej - majątek, zatrudnienie, dochody, informacje o pozostałym zadłużeniu.

2. W przypadku osoby prawnej i jednostki organizacyjnej nieposiadającej osobowości prawnej - analiza wyników finansowych (wypłacalność, rentowność), ocena sprawności działania, ocena płynności finansowej, historia współpracy z bankami.

Wymienione obszary badania zdolności kredytowej pokazują kierunek i kryteria, którymi kieruje się bank w procesie weryfikacji wniosku kredytowego. Zasadniczo dzielimy je na kryteria subiektywne i obiektywne. Ostatecznie część wniosków jest opiniowana negatywnie. Stanowi to prawo i obowiązek wierzyciela, jakim jest bank. Zastanawiające jest z punktu widzenia psychologii społecznej, dlaczego klienci odrzuconych wniosków kredytowych nie akceptują tej informacji. Przeciwnie, uważają, że są większymi „fachowcami” w ocenie swojej zdolności kredytowej i zamiast restrukturyzować finanse domu, obniżają swoją wrażliwość na usługi finansowe oferowane 
przez rynek pozabankowy i bezwzględnie dążą do dalszego zadłużania się. W tym artykule jest pomijane zjawisko, iż część osób fizycznych świadomie zaciąga pożyczki z zamiarem bezpośrednim „wyłudzenia” pożyczanej kwoty pieniężnej, bez zamiaru jej zwrotu.

Kredyt bankowy jest umową zawartą w formie pisemnej pomiędzy bankiem a kredytobiorcą. Bank w umowie kredytu zobowiązuje się dać do dyspozycji kredytobiorcy na czas oznaczony w umowie kwotę środków pieniężnych z przeznaczeniem na ustalony cel. Natomiast kredytobiorca zobowiązuje się do korzystania z kredytu na warunkach określonych w umowie, zwrotu kwoty wykorzystanego kredytu wraz z odsetkami w oznaczonych terminach spłaty oraz zapłaty prowizji od udzielonego kredytu.

Cechy kredytu bankowego są następujące:

1. Umowa kredytowa zostaje zawarta $z$ chwilą jej podpisania przez obie strony. Bank musi postawić do dyspozycji kredytobiorcy określoną kwotę - nawet jeśli zmienią się np. warunki rynkowe.

2. Umowa kredytu jest dwustronnie zobowiązująca. Bank zobowiązuje się do udostępnienia kredytobiorcy określonej kwoty pieniędzy, a kredytobiorca - do korzystania z tej kwoty na warunkach określonych w umowie i do jej zwrotu wraz z odsetkami w określonym terminie.

3. Kredyt jest odpłatny. Bank za udostępnione kredytobiorcy środki pobiera zapłatę w postaci odsetek, prowizji, a w przypadku opóźnienia w spłacie kredytu - odsetek za zwłokę.

4. Kredyt jest pieniężny. Bank stawia do dyspozycji kredytobiorcy określoną kwotę pieniędzy.

5. Kredyt jest celowy. Sposób wykorzystania środków jest zawsze z góry określony.

W procesie ubiegania się o kredyt nie należy zapominać, iż pociąga to za sobą dodatkowe koszty. Koszt pożyczki (kredytu) to suma kosztów, które wnioskodawca (kredytobiorca) będzie musiał ponieść w związku z zawartą umową o kredyt. W szczególności chodzi o odsetki, marże oraz prowizje. Występują również koszty dodatkowych niezbędnych usług, np. ubezpieczenia. Formy zabezpieczenia kredytu stosowane przez banki dzielimy na osobowe (poręczenie) i rzeczowe (hipoteka, zastaw rejestrowy). Prawo bankowe 
określa niezbędne elementy umowy kredytowej. Ustawodawca stanowi, że umowa kredytowa powinna być zawarta w formie pisemnej oraz zawierać określone w ustawie elementy. W szczególności umowa powinna precyzować i umożliwić identyfikację strony umowy kredytowej.

Podstawy prawne i zasady zaciągania kredytów na rynku pozabankowym wynikają przede wszystkim z Ustawy z dnia 12 maja 2011 r. o kredycie konsumenckim (Dz.U. z 2016 r. poz. 1528, z 2017 r. poz. 819) lub tylko z Kodeksu cywilnego. Na marginesie należy zauważyć, iż zgodnie z art. 3 ust 2 pkt 2 ustawy o kredycie konsumenckim za kredyt konsumencki uważa się również umowę kredytu w rozumieniu przepisów prawa bankowego.

Oznacza to, że istotna różnica pomiędzy rynkiem bankowy i rynkiem pozabankowym sprowadza się do tego, że bank jako instytucja zaufania publicznego musi stosować rygorystyczne procedury, badając zdolność kredytową i historię dotychczasowego spłacania zobowiązań przez potencjalnego klienta. W tym celu korzysta z BIK-u i innych scentralizowanych systemów. Natomiast firmy pożyczkowe, tzw. „chwilówki”, w ogóle nie stosują wspomnianych narzędzi, pożyczając własne pieniądze, stosują niekonwencjonalne sposoby weryfikacji klienta, a następnie windykację należności.

Kryterium umożliwiające rozgraniczenie rynku bankowego i pozabankowego stanowi art. 5 pkt 2 ustawy o kredycie konsumenckim, zgodnie z którym kredytodawcą jest przedsiębiorca w rozumieniu przepisów Ustawy z dnia 23 kwietnia 1964 r. - Kodeks cywilny, który w zakresie swojej działalności gospodarczej lub zawodowej udziela lub daje przyrzeczenie udzielenia konsumentowi kredytu.

W tym kontekście należy zauważyć, iż rynek pozabankowy tworzą przede wszystkim kredytodawca (art. 5 pkt 2 ustawy o kredycie konsumenckim) wraz z pośrednikiem kredytowym (art. 5 pkt 3 ustawy o kredycie konsumenckim). Właściwe „zdiagnozowanie” kredytów i pożyczek udzielanych przez rynek pozabankowy jest bardzo utrudnione. Zasadniczo postanowienia ustawy o kredycie konsumenckim budzą wątpliwości interpretacyjne i doświadczenie wskazuje, że są omijane przez kredytodawców. Chodzi o ustawowe przesłanki kredytu konsumenckiego. Przykładowo stosownie do brzmienia postanowień art. 3 ust. 2 pkt 3 ustawy o kredycie konsumenckim za umowę kredytu konsumenckiego rozumie się: umowę o odroczeniu konsumentowi terminu 
spełnienia świadczenia pieniężnego, jeżeli konsument jest zobowiązany do poniesienia jakichkolwiek kosztów związanych $\mathrm{z}$ odroczeniem spełnienia świadczenia. W przypadku udzielenia pożyczki na okres jednego miesiąca, bez jakichkolwiek kosztów zastosowanie mają tylko i wyłącznie ogólne przepisy Kodeksu cywilnego. Firmy pożyczkowe sprytnie układają postanowienia umów tak, aby nie wchodziły w zakres ustawy o kredycie konsumenckim. Reklamują umowy miesięczne bez oprocentowania. Po miesiącu dokonują prolongaty terminu spłaty, ale wynagrodzenie określają jako opłatę. To termin bardzo ogólny, który ma umożliwić obejście przepisów omawianej ustawy.

Sposobów na obejście ustawy na rynku pozabankowym stosowanych jest wiele, co wywołuje piramidalny wzrost pożyczek udzielanych wyłącznie w oparciu o Kodeks cywilny.

Pozornie obraz badanego zjawiska jest klarowny. W rzeczywistości jest on bardzo zagmatwany dla samych pożyczkobiorców, jak i dla organów państwa. Przepisy ustawy o kredycie konsumenckim w odniesieniu do banków i SKOK-ów nie powodują wątpliwości, co zostało przybliżone przy omówieniu rynku bankowego. W przypadku innych podmiotów o statusie „kredytodawcy” ustawodawca również przewiduje badanie zdolności kredytowej, korzystanie $\mathrm{z}$ baz danych itd. Jednak fakt, że te instytucje pozostają poza nadzorem bankowym KNF-u, sprowadza się do uznaniowego badania przez nie zdolności kredytowej kredytobiorcy. Brakuje standaryzowania usług finansowych na poziomie gwarantującym przyszłe bezpieczeństwo pożyczkobiorcy. Pociąga to za sobą wiele niebezpiecznych skutków w poszczególnych sferach życia pożyczkobiorcy.

Przede wszystkim procedury wewnętrze kredytodawców na rynku pozabankowym są ich wewnętrzną sprawą, czyli pozostają bez nadzoru zewnętrznego. To spowodowało, że firmy pożyczkowe przede wszystkim stosują niekonwencjonalne sposoby pozyskiwania klienta, jak również oceny zdolności kredytowej i współpracy z pożyczkobiorcą.

Doświadczenia kancelarii prawnych wskazują, iż pośrednicy kredytowi działający na rzecz firm pożyczkowych pozyskują klientów na zasadzie piramidy. Udzielając pożyczki osobie fizycznej, zachęcają, aby wskazała inne osoby, które także mogłyby być nią zainteresowane. Oferta na starcie jest szokująco elastyczna, dostępna i realizowana dosłownie „od ręki”. Pośrednik 
finansowy działa jednocześnie jako kasjer i wypłaca określoną kwotę pożyczki. Ten sam pośrednik funkcjonuje również jako windykator. Co do kryteriów oceny zdolności kredytowej, nie ma możliwości zapoznania się z oficjalnymi procedurami rynku pozabankowego. Kolejny raz odwołując się do doświadczeń kancelarii prawnych, należy zauważyć przede wszystkim stosowanie socjotechnik. Pośrednik kredytowy ustala pewne punkty odniesienia. Czy jest emerytura (pewne źródło egzekucji)? Jaki jest posiadany majątek? Kim jest w społeczeństwie klient? Gdzie pracują jego dorosłe dzieci? Te przykłady korespondują z późniejszymi praktykami firm pożyczkowych. Klient zaczynający współpracę z pożyczką w kwocie 1 tys. zł zaciągniętą na okres jednego miesiąca, nie mogąc się z niej wywiązać, korzysta z przyjaznej ręki pośrednika. Zaciąga kolejną, płacąc kilkaset złotych za prolongatę terminu spłaty, jednocześnie zwiększając minimalnie kwotę główną pożyczki. Rozpatrując tę sytuację psychologicznie, można powiedzieć, iż pożyczkobiorca kolejny raz otrzymał mały zastrzyk finansowy i popada w dalszy stan spokoju. W rzeczywistości wg symulacji KNF-u osoby fizyczne pożyczające 1 tys. zł po kilkunastu miesiącach i kilkunastu przedłużeniach wykazują zadłużenie w wysokości ok. 17 tys. zł. Zaczyna się wtedy działanie spirali finansowej rozumianej jako spirala zadłużenia bez możliwości samodzielnej spłaty długu przez pożyczkobiorcę (Pluta, Michalski, 2013, s. 1-8).

Wówczas firma pożyczkowa rozpoczyna techniki windykacyjne adekwatne do informacji o kliencie i bardzo skuteczne. Wielokrotne odwiedziny w domu dłużnika, naklejanie informacji o zadłużeniu na drzwiach, głośne upominanie się o dług w miejscach publicznych (pod kościołem, przy kasie w sklepie), oklejanie drzwi domu taśmą informującą o windykacji. Taśma przypomina znaki używane przez komornika. Kolejnym stadium jest informowanie o zadłużeniu np. dorosłych dzieci pożyczkobiorcy. Dorosłe dzieci po powzięciu wiadomości o jego zadłużeniu dość często dokonują dobrowolnej spłaty za rodzica. Znane są przypadki krótkotrwałego pozbawienia wolności przez pośrednika kredytowego stosowane wobec starszych osób, które wsiadły do jego samochodu, aby tłumaczyć swoją niewypłacalność. Windykator przetrzymując w samochodzie pożyczkobiorcę, straszy zawiadomieniem policji o wyłudzeniu kredytu i poinformowaniem o tym ważnych dla niego osób itd. Osoby słabe i poczuwające się do obowiązku 
spłaty zadłużenia po kilku minutach spędzonych w samochodzie windykatora ostatecznie są uwalniane i wysiadają, przeżywając ogromną traumę.

Naturalnie w przypadku nieskuteczności form presji stosowanych wobec pożyczkobiorcy będącemu w spirali zadłużenia kredytodawca kieruje sprawę do sądu. Kredytodawca stosuje stałe umowy z kancelariami, które $\mathrm{w}$ postępowaniach upominawczych szybko uzyskują prawomocne nakazy zapłaty (Majewska, 2015, s. 17-19). W konsekwencji następują zajęcia świadczeń emerytalnych, rzeczy ruchomych i nieruchomych. Dramat rodziny bardzo często jest bardziej złożony. Małżonek zadłużający się w firmach pożyczkowych nie informuje o tym współmałżonka. Gdy ostatecznie spirala zadłużenia zostaje ujawniona, następują rozpady rodzin, procesy o ustalenie rozdzielności majątkowej z datą wsteczną, procesy rozwodowe, ale niestety również próby samobójcze.

Według aktualnej Diagnozy Społecznej 2015... aż 34\% gospodarstw domowych w Polsce posiada pożyczki (kredyty). Stanowi to 4,6 mln zadłużonych gospodarstw domowych. Przyczyna tak znacznego zadłużenia Polaków wynika z dostępności produktów kredytowych, ale także z braku wyobraźni o skutkach perspektywicznych podejmowania nieprzemyślanych decyzji finansowych.

\section{JAK UNIKNĄĆ SPIRALI FINANSOWEJ}

Aby zapobiec powstaniu spirali finansowej, należy zaciągać jedynie pożyczki, na które stać wnioskodawcę. Zwykła analiza sprowadzająca się do porównania przychodów i wydatków umożliwia ocenę, czy daną osobę stać na terminowe spłacenie całej należności wynikającej z zaciągniętej pożyczki (Antczak, 2017, s. 147-160).

Ważne jest również staranne przeanalizowanie postanowień projektu umowy z pożyczkodawcą. Podpisując umowę pożyczki, wnioskodawca powinien mieć pewność, że wszystkie postanowienia projektu umowy są dla niego zrozumiałe. Warto zwrócić uwagę np. na konsekwencje nieterminowej spłaty, w szczególności jaka jest przewidziana wysokość odsetek w takim przypadku.

Zgodnie $\mathrm{z}$ art. 6b ust. 1 Ustawy z dnia 21 lipca 2006 r. o nadzorze nad rynkiem finansowym (Dz.U. z 2016 r. poz. 174, ze zm.) KNF podaje do publicznej wiadomości informacje o złożonych przez siebie zawiadomieniach 
o podejrzeniu popełnienia przestępstwa określonego w art. $215 \mathrm{i}$ art. 216 Ustawy z dnia 28 sierpnia 1997 r. o organizacji i funkcjonowaniu funduszy emerytalnych oraz art. 171 ust. 1-3 ustawy Prawo bankowe.

Zgodnie z art. 6b ust. 6 Ustawy z dnia 21 lipca 2006 r. o nadzorze nad rynkiem finansowym KNF informuje także o postępowaniach karnych prowadzonych z urzędu lub w wyniku zawiadomienia złożonego przez podmiot inny niż KNF, w przypadku których Przewodniczący KNF skorzystał $\mathrm{z}$ uprawnienia pokrzywdzonego w postępowaniu karnym.

Konieczne jest zintensyfikowanie kampanii medialnych ostrzegających o skutkach zaciągania pożyczek w firmach pożyczkowych. Ponadto w przypadku wystąpienia spirali zadłużenia najgorszym rozwiązaniem jest niemówienie o tym domownikom, niekorzystanie z porad prawnych i przysługującej obywatelowi ochrony prawnej.

\section{RzeCznik Finansowy}

Ustawa $\mathrm{z}$ dnia 5 sierpnia 2015 r. o rozpatrywaniu reklamacji przez podmioty rynku finansowego i o Rzeczniku Finansowym określa główne zasady działania Rzecznika Finansowego. Rzecznik Finansowy został powołany $\mathrm{w}$ celu wspierania klientów w sporach z podmiotami rynku finansowego. Niestety jego działalność dotyczy tylko pierwszego obszaru wskazanego w powyższym artykule z rozszerzeniem na te umowy pożyczek, które spełniają kryteria ustawy o kredycie konsumenckim. Rzecznik Finansowy pomaga w różny sposób: od poradnictwa, przez interwencje i postępowania polubowne, aż po wsparcie $\mathrm{w}$ trakcie postępowania sądowego. Warto także wskazać rozporządzenie Ministra Rozwoju i Finansów z dnia 15 lutego 2017 r. w sprawie pozasądowego postępowania przed Rzecznikiem Finansowym (określa ono zasady tzw. postępowań polubownych przy Rzeczniku Finansowym).

\section{ProponoWANA PROCEDURA POSTĘPOWANIA W PRZYPADKU ZAISTNIENIA SPIRALI ZADEUŻENIA}

KROK 1. Procedura reklamacji w instytucji finansowej. W pierwszej kolejności należy złożyć pisemną lub mailową reklamację w instytucji finansowej. Szczegółowo opisać zastrzeżenia dotyczące produktu finansowego 
oraz określić sposób rozpatrzenia reklamacji. Wystąpienie trudności w sformułowaniu reklamacji jest sygnałem, iż należy skorzystać z pomocy instytucji wskazanych w kroku 2. Instytucje finansowe są zobowiązane udzielać odpowiedzi bez zbędnej zwłoki, jednak nie później niż w terminie 30 dni od dnia otrzymania reklamacji. W szczególnie skomplikowanych przypadkach odpowiedź może być udzielona w terminie nie dłuższym niż 60 dni od dnia otrzymania reklamacji.

KROK 2. Porady i interwencje. Bezpłatnych porad w zakresie sporu z podmiotem rynku finansowego udziela Rzecznik Finansowy oraz powiatowy lub miejski rzecznik konsumentów. Pomoc można uzyskać również w pozarządowych organizacjach konsumenckich, np. Federacji Konsumentów i Stowarzyszeniu Konsumentów Polskich. Rzecznik konsumentów oraz organizacje konsumenckie udzielają porad prawnych dotyczących ochrony interesów konsumentów. Ponadto podejmują w imieniu konsumentów interwencje, udzielają im pomocy w kierowaniu spraw na drogę sądową oraz w ich prowadzeniu. Rzecznik Finansowy rozpatruje skargi i wnioski klientów rynku finansowego związane z niesłuszną odmową uznania reklamacji przez podmiot rynku finansowego. Rzecznik może wystąpić na drogę sądową na rzecz klienta w sprawach dotyczących nieuczciwych praktyk rynkowych w zakresie działalności podmiotów rynku finansowego. Ponadto rzecznik może przystąpić do toczącego się postępowania sądowego, za zgodą powoda.

KROK 3. Alternatywne metody rozwiązywania sporów. Strony umowy kredytowej w ramach szczegółowych ustaleń mogą postanowić o rozwiązaniu sporu na drodze pozasądowej. Istnieją trzy główne instytucje oferujące możliwość pozasądowego załatwienia sporu: Sąd Polubowny przy KNF-ie, Rzecznik Finansowy oraz Bankowy Arbitraż Konsumencki.

KROK 4. Rozstrzyganie sporów przed sądem powszechnym. W przypadku gdy realizacja kroków 1-3 nie przyniosła rezultatu, pozostaje możliwość dochodzenia roszczeń w drodze postępowania cywilnego. Należy rozważyć ewentualne skorzystanie z profesjonalnej porady prawnej. Bezpłatną pomoc prawną można uzyskać u rzeczników konsumentów i w organizacjach konsumenckich. Ponadto właściwej pomocy prawnej udzielają radcowie prawni oraz adwokaci. 
Jednym z ostatecznych rozwiązań jest upadłość konsumencka - redukcja lub umorzenie zobowiązań osoby fizycznej nieprowadzącej działalności gospodarczej w przypadku zaistnienia niezawinionej niewypłacalności - wprowadzona 31 marca 2009 r. do polskiego prawa upadłościowego i naprawczego (Dz.U. z 2017 r. poz. 2344). 31 grudnia 2014 r. weszła w życie nowelizacja upadłości konsumenckiej, istotnie liberalizująca przesłanki ogłoszenia upadłości. Mimo to upadłość konsumencka jest rzadko stosowana, tylko niewielka część społeczeństwa posiada wiedzę i swoistą odwagę, aby podjąć próbę jej przeprowadzenia.

Naturalnie niektórzy pożyczkobiorcy działając na granicy prawa, odpowiednio przygotowują się do nieuniknionej egzekucji i dokonują pewnych czynności mających złagodzić trudną sytuację bytową rodziny w sytuacji egzekucji (Hinc, 2009, s. 33-46).

Przedmiotowa analiza aspiruje do bycia wywodem prawno-naukowym, co ogranicza dosłowne ujęcie problemu. Mimo to należy stwierdzić, że po wyczerpaniu się wspomnianych kroków i wszelkich form obrony pożyczkobiorcy przed totalnymi skutkami spirali zadłużenia można zastosować ostateczne rozwiązanie, jakim jest nauczenie się żyć z jej skutkami. Jest to wynik obserwacji z punktu widzenia kancelarii prawnych - po wyczerpaniu się wszystkich środków prawnych ochrony pożyczkobiorcy i po oczywistej destrukcji życia rodzinnego paradoksalnie następuje przewartościowanie. Okazuje się, że osoby fizyczne jednak mogą żyć dalej i powinny żyć mimo zaistnienia zupełnej niewypłacalności. Współcześnie za długi nikt nie popada w stan „niewolniczy”, ponadto w XXI w. w Polsce twarde przestępcze egzekwowanie długów nie ma miejsca. Oczywiście, jak tu wspomniano, występują czyny z pogranicza prawa karnego, ale po pewnych zmianach możliwe jest funkcjonowanie. Niekiedy dłużnik musi zmienić miejsce zamieszkania, traci dom, więc warunki bytowe są zaspokajane w sposób odbiegający od idealnego. Niestety ostatecznie może się okazać, że będzie koniczne funkcjonowanie w szarej strefie finansów (Kaniewska, 2017, s. 283-300).

Omówiony problem spirali finansowej stanowi narastające zagrożenie dla bezpieczeństwa społecznego a jednocześnie bezpieczeństwa finansowego kraju. Problem dotyczący działalności sektora pozabankowego i standardów świadczenia usług finansowych pozostaje ciągle nierozwiązany (Sitek, 2015, s. 11-36). 


\section{WNIOSKI DE LEGE FERENDA I DE LEGE LATA}

Reasumując, można stwierdzić, że omówione zagadnienia dotyczące stosowania ustawy o kredycie konsumenckim są w dużym stopniu obchodzone. Przedstawione przykłady luk i praktycznych interpretacji na gruncie obowiązujących przepisów są nieakceptowalne w nowoczesnym państwie prawna.

Trudno jest kierować wnioski de lege ferenda zakładające np. objęcie nadzorem bankowym rynku pozabankowego, tak aby wszystkie produkty finansowe były pod nadzorem KNF-u. Zniekształciłoby to ideę przyświecającą wprowadzeniu ustawy o kredycie konsumenckim i liberalizację rynku usług finansowych. Mimo to należałoby rozważyć zmiany ustawy w większym stopniu „uszczelniające” pojęcie umowy kredytu konsumenckiego. Drugim wnioskiem de lege ferenda jest wprowadzenie mechanizmu prawnego lub chociaż sankcji za brak uczestnictwa kredytobiorcy w scentralizowanym systemie informacji o kredytach udzielonych w całym systemie usług finansowych. Otworzyłoby to problem dodatkowych kosztów, jakie ponieśliby kredytodawcy w związku z opłatami za figurowanie w ogólnopolskiej bazie kredytobiorców. Konieczna byłaby właściwa ocena skutków takiej regulacji. Niezależnie od ryzyka, że oszacowane koszty zostałyby przerzucone na klientów, problem spirali zadłużenia na rynku pozabankowym narasta i w coraz większym stopniu negatywnie oddziałuje na osoby fizyczne i gospodarstwa domowe.

\section{Literatura}

Antczak, B.O. (2017). Modele edukacji - między humanizmem a komercja, „Journal of Modern Science" 4/35. ISSN 1734-2031.

Bywalec, C. (2012). Ekonomika i finanse gospodarstw domowych, Warszawa: Wydawnictwo Naukowe PWN. ISBN 9788301168230.

Grzywińska-Rąpca, M. (2018). Modelowanie poziomu wynagrodzeń w Polsce, „Journal of Modern Science" 1/36. ISSN 1734-2031.

Hinc, A. (2009). Budżet domowy pod ostrzałem. Czego nie wiedza ludzie mający problemy finansowe?, Gliwice: Wydawnictwo Złote Myśli. ISBN 9788375828405.

Kaniewska, M. Klimski, M. (2017). Global Policy of Eradicating Poverty. The Aspect of Education, „Journal of Modern Science” 4/35. ISSN 1734-2031.

Majewska, R. (2015). Potrącenia z wynagrodzeń i zasiłków. Egzekucja i potrącenia dobrowolne, Warszawa: Wydawnictwo C.H. Beck. ISBN 9788325574635. 
Pluta, W. Michalski, G. (2013). Krótkoterminowe zarzadzanie kapitałem. Jak zachować plynność finansową?, Warszawa: C.H. Beck. ISBN 9788325555405.

Raport NBP o stabilności systemu finansowego. Styczeń 2017.

Sitek, P. (2015). The economic security of the State and the banking union, Saarbru-cken: Lambert Academic Publishing.

Wichrowski, G. (2017). Upadłość konsumencka. Kraków: Ridero. ISBN 9788381045186.

\section{Akty prawne}

Ustawa z dnia 5 listopada 2009 r. o spółdzielczych kasach oszczędnościowo-kredytowych (Dz.U. z 2012 r. poz. 855 i 1166 ze zm.).

Ustawa z dnia 21 lipca 2006 r. o nadzorze nad rynkiem finansowym (Dz.U. z 2016 r. poz. 174 , ze zm.).

Ustawa z dnia 29 sierpnia 1997 r. Prawo bankowe (Dz.U. z 2017 r. poz. 1876, 2361).

Ustawa z dnia 12 maja 2011 r. o kredycie konsumenckim (Dz.U. z 2016 r. poz. 1528, z 2017 r. poz. 819).

Ustawa z dnia 23 kwietnia 1964 r. Kodeks cywilny (Dz.U. z 2017 r. poz. 459, 933, 1132).

\section{Źródła internetowe}

Biekieszczuk, K. Nadzór KNF nad spółdzielczymi kasami oszczędnościowo-kredytowy$m i$, http://www.bibliotekacyfrowa.pl/Content/38948/002.pdf (dostęp: 15.05.2015).

Diagnoza Społeczna 2015. Warunki i jakość życia Polaków. Tekst dostępny online: http://www.diagnoza.com/pliki/raporty/Diagnoza_raport_2015.pdf (dostęp: 12.02.2018).

http://gpwmedia.pl/wiadomosci/14535/nbp_polski_system_finansowy_jest_stabilny/\#sthash.WKIlDQ53.dpuf (dostęp: 20.01.2018).

http://www.nbp.pl/publikacje/integracja_europejska/nowa_architektura_nadzoru_ finansowego_w_ue_postep_prac_07_2010.pdf (dostęp: 8.01.2018). 